Article

\title{
Surveillance Study of Hepatitis E Virus (HEV) in Domestic and Wild Ruminants in Northwestern Italy
}

\author{
Andrea Palombieri ${ }^{1}$, Serena Robetto ${ }^{2}$, Federica Di Profio ${ }^{1}$, Vittorio Sarchese ${ }^{1}$, Paola Fruci ${ }^{1}$, \\ Maria Cristina Bona ${ }^{2}$, Giuseppe $\mathrm{Ru}^{2}{ }^{2}$, Riccardo Orusa ${ }^{2}$, Fulvio Marsilio ${ }^{1}$ (D, Vito Martella ${ }^{3}$ (D) and \\ Barbara Di Martino ${ }^{1, *}$ (D) \\ 1 Faculty of Veterinary Medicine, Università degli Studi di Teramo, 64100 Teramo TE, Italy; \\ apalombieri@unite.it (A.P.); fdiprofio@unite.it (F.D.P.); vsarchese@unite.it (V.S.); pfruci@unite.it (P.F.); \\ fmarsilio@unite.it (F.M.) \\ 2 Istituto Zooprofilattico Sperimentale del Piemonte, Liguria e Valle d'Aosta (IZS PLV), 11020 Quart AO, Italy; \\ serena.robetto@izsto.it (S.R.); cristina.bona@izsto.it (M.C.B.); giuseppe.ru@izsto.it (G.R.); \\ riccardo.orusa@izsto.it (R.O.) \\ 3 Department of Veterinary Medicine, Università Aldo Moro di Bari, Valenzano, 70121 Bari BA, Italy; \\ vito.martella@uniba.it \\ * Correspondence: bdimartino@unite.it; Tel.: +39-0861-266845
}

Received: 18 November 2020; Accepted: 8 December 2020; Published: 9 December 2020

Simple Summary: Hepatitis E virus (HEV) infection can cause both acute and chronic hepatitis in humans and represents an emerging public health concern worldwide. In developed countries, zoonotic transmission of HEV genotypes 3 and 4 is caused by ingestion of raw or undercooked meat of infected swine or wild boars, the main reservoirs of HEV. However, in the last few years, molecular and serological evidence seem to indicate that several other animal species may act as HEV host, including domestic and wild ruminants. In this study, serum and fecal specimens from sheep, goats, red deer, roe deer, chamois, and Alpine ibex collected in two northwestern Italian regions (Piemonte and Valle d'Aosta) were screened molecularly and serologically. With the exception of chamois, HEV antibodies were found both in the domestic and wild ruminant species investigated with the highest rates in sheep and goats. These findings demonstrate that wild also domestic ruminants may be implicated in the viral cycle transmission.

Abstract: In industrialized countries, increasing autochthonous infections of hepatitis E virus (HEV) are caused by zoonotic transmission of genotypes (Gts) 3 and 4, mainly through consumption of contaminated raw or undercooked pork meat. Although swine and wild boar are recognized as the main reservoir for Gt3 and Gt4, accumulating evidence indicates that other animal species, including domestic and wild ruminants, may harbor HEV. Herein, we screened molecularly and serologically serum and fecal samples from two domestic and four wild ruminant species collected in Valle d'Aosta and Piemonte regions (northwestern Italy. HEV antibodies were found in sheep (21.6\%), goats (11.4\%), red deer $(2.6 \%)$, roe deer $(3.1 \%)$, and in Alpine ibex (6.3\%). Molecular screening was performed using different primer sets targeting highly conserved regions of hepeviruses and HEV RNA, although at low viral loads, was detected in four fecal specimens $(3.0 \%, 4 / 134)$ collected from two HEV seropositive sheep herds. Taken together, the data obtained document the circulation of HEV in the geographical area assessed both in wild and domestic ruminants, but with the highest seroprevalence in sheep and goats. Consistently with results from other studies conducted in southern Italy, circulation of HEV among small domestic ruminants seems to occur more frequently than expected.

Keywords: hepatitis E virus (HEV); domestic and wild ruminants; HEV antibodies; viral RNA 


\section{Introduction}

Hepatitis E virus (HEV) infection is a major health problem worldwide. HEV typically causes self-limiting acute viral hepatitis, although chronic infection with neurological and other extrahepatic manifestations has also been reported [1]. HEV is a quasi-enveloped [2,3] single-stranded positive-sense RNA virus of approximately 27 to $34 \mathrm{~nm}$ in diameter, classified in the family Hepeviridae, genus Orthohepevirus, which comprises 4 species, Orthohepevirus $A$ to $D$ [4]. Based on the full-length genome analysis, HEV strains within the species Orthohepevirus $A$ have been assigned to at least eight distinct genotypes (Gt1-Gt8) [5], with four major Gts (1-4) implicated in human infection. Gt1 and Gt2 are restricted to humans and associated with large, waterborne outbreaks of disease in tropical and subtropical areas [1]. In contrast, Gt3 and Gt4 are zoonotic and cause sporadic and cluster cases of hepatitis $\mathrm{E}$ in both industrialized and developing countries [6,7]. Gt5 and Gt6 have been detected only in wild boars in Japan [8], whilst Gt7 and Gt8 from dromedary camels in United Arab Emirates [9] and from Bactrian camels in China [10], respectively. Except for Gt7, identified from a chronically infected human liver transplant patient who consumed camel milk and meat [11], the zoonotic potential of Gt5, Gt6, and Gt8 is still unclear.

Consumption of poorly cooked or raw pork meat is considered the major source of human infection by Gt3 and Gt4 HEVs with domestic pigs and wild boars identified as the main animal reservoirs [12]. Since the first identification of Gt3 HEV in swine [13], several molecular and serological surveys showed high prevalence in pigs and wild boars worldwide [12]. In Europe, investigations performed in swine herds revealed seroprevalences estimated between $30 \%$ and $100 \%$ [14-23] with molecular detection rates of $0.9 \%$ to $87.5 \%$ [24-33]. Similarly, epidemiological studies performed in wild boar populations reported antibody detection rates ranging from $12.5 \%$ to $57.4 \%$ and molecular prevalence of $0.3 \%$ to $68.2 \%$ [12,19,34-38]. Transmission from deer to humans has also been described [39,40], although they mostly undergo spill-over HEV infections in contaminated habitat shared with wildlife reservoirs [12,41]. Evidence for HEV zoonotic transmission by ingestion of uncooked deer meet was first reported in 2003 in Japan [39] during an outbreak of acute hepatitis involving four members of the same family that consumed deer raw meat (Sika deer, Cervus nippon nippon). Molecular analysis of frozen leftover meat portions revealed the presence of Gt3 HEV RNA, showing 100\% nucleotide identity to the sequences identified in human patients [39].

Molecular surveys performed in wild ruminants in Europe have reported prevalence ranging from $1.2 \%$ to $16.0 \%$ in red deer (Cervus elaphus) [41-49] and from $3.3 \%$ to $34.4 \%$ in roe deer (Capreolus capreolus) [41-43,49,50]. Accumulating literature worldwide suggests that besides wilds, domestic ruminants, like sheep and goats, may also harbor HEV [51-57], posing additional risks for zoonotic infection. Gt4 HEV sequences genetically closest to strains identified in swine and humans, were first detected in liver specimens collected from slaughtered sheep in the Xinjiang region (China) in a 2015 study [56]. Subsequently, similar strains have been also found in stool, serum and milk samples collected from goat herds in Yunnan Province (China) [52]. In the European continent, the identification of Gt3 strains in goat farms has been already documented in Italy [51], during a survey performed in a restricted geographical area (Abruzzo, southern Italy). In the same area, HEV has also been detected at high rate in wild boars [58]. Serological and molecular screening of seven small sheep farms located in the same region has revealed seroprevalence rates ranging from $6.6 \%$ to $38.3 \%$ and has identified HEV strains genetically related to those detected locally in goats, wild boars, and humans $[54,59]$.

In this study, in order to gather data on HEV epidemiology in other geographical areas, a large serological and molecular investigation was performed by assessing collections of serum and fecal samples from domestic and wild ruminants sharing the same habitats in two northwestern Italian regions (Valle d'Aosta and Piemonte). 


\section{Materials and Methods}

\subsection{Sampling}

A total of 416 domestic and wild ruminants were screened for the presence of HEV antibodies and viral RNA. In more detail, between September 2017 and December 2019, serum and fecal samples were collected from 134 sheep and 167 goats, collected respectively in five ovine and sixteen caprine farms from 5 municipalities in the area of Cuneo (Piemonte region) and from 15 municipalities in the Valle d'Aosta region (Figure 1a). The flock size ranged from 6 to 75 sheep and from 5 to 90 goats. All animals, free to graze on pastures, were clinically healthy at the time of sampling and were divided on the basis of age in groups $<3$ years, 3-4 years, and $>4$ years. The circulation of $\mathrm{HEV}$ in wild ruminants was investigated mainly in the Valle d'Aosta region, where ungulates wildlife are very abundant and contact between them and domestic livestock can occur easily since pastures overlap with the feeding areas of red deer (Cervus elaphus), roe deer (Capreolus capreolus), and chamois (Rupicapra rupicapra). Briefly, one hundred and fifteen paired fecal and serum specimens were collected from 38 red deer, 32 roe deer, and 13 chamois sampled during the regular hunting season (from September 9 to December 18) in Valle d'Aosta and submitted to the National Reference Centre for Wild Animal Diseases (CeRMAS-IZS PLV). In addition, 32 Alpine ibex (Capra ibex) samples obtained during species control activity in province of Torino (Piemonte Region) $(n=2)$ and in Valle d'Aosta $(n=30)$, were included in the serological and molecular screening (Figure 1b). Fecal and serum specimens were placed in isothermal boxes using ice bags, transferred in the lab and kept frozen at $-80{ }^{\circ} \mathrm{C}$ until tested.
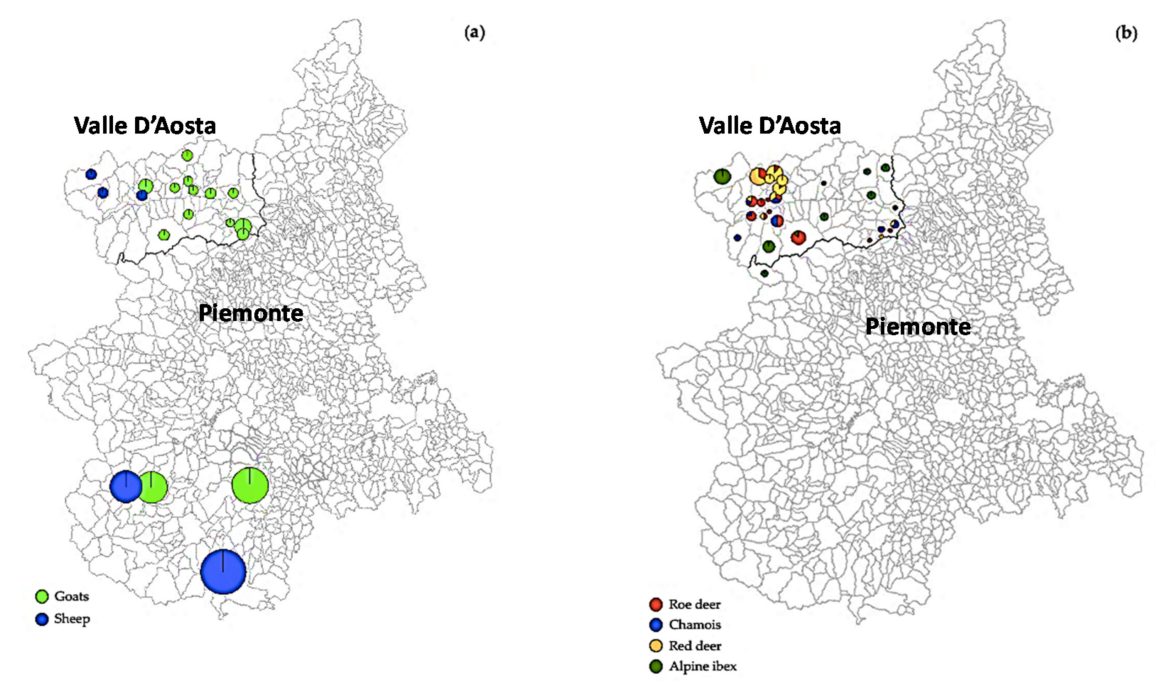

Figure 1. Mapping of sheep and goat farms (a) investigated and sites (b) in which wild ruminants were sampled.

\subsection{Serological Assay}

All serum samples were screened for the presence of $\mathrm{HEV}$ antibodies by using a species-independent commercial double-antigen sandwich enzyme-linked immunosorbent assay (ELISA) kit (Wantai Biological, Beijing, China), based on the peptide E2 spanning amino acids 394-606 of the major structural protein of HEV Gt1 (GenBank accession number D11092) [60]. ELISA test was performed following all the manufacturer's instructions. Absorbance was measured at $450 \mathrm{~nm}$ $\left(\mathrm{OD}_{450}\right)$ using a Multiskan automatic plate reader (ThermoLabsystems, Abu Gosh, Israel). For each test, the cut-off value was calculated as $\mathrm{Nc}+0.12(\mathrm{Nc}=$ the mean absorbance value for three negative controls).

When comparing with other HEV antibody detection ELISAs, the assay employed in this study was found to have a high sensitivity, although it seems to possess a lower specificity [61].This antigen, 
widely used to detect Gt1-Gt4 HEV antibodies in humans, has also been successfully used to evaluate HEV seroconversion in animals infected either under natural or experimental conditions with novel members of the species Orthohepevirus A, such as Gt7 and Gt8 [62,63], as well as to detect specific IgG antibodies in ferrets and foxes that tested positive, on molecular investigations, for Orthohepevirus C RNA [64,65].

\subsection{Molecular Assay}

Fecal samples were homogenized in phosphate-buffered saline $(0.15 \mathrm{M}, \mathrm{pH} 7.2)$ to obtain a total of $1 \mathrm{~mL}$ and then centrifuged at $10,000 \times g$ for $3 \mathrm{~min}$. Each fecal specimen was seeded with $50 \mu \mathrm{L}$ of feline calicivirus strain F9 (ATCC ${ }^{\circledR}$ VR-782 ${ }^{\mathrm{TM}}$ ) at the final titer of $4 \times 10^{6}$ as RNA extraction control, and to test for the presence of inhibitors. Total RNA was extracted individually from each fecal $(0.5 \mathrm{~mL})$ and serum $(0.5 \mathrm{~mL})$ specimen by using the TRIzol LS (Invitrogen, Ltd., Paisley, UK), following the manufacturer's instructions.

The presence of Orthohepevirus A RNA was assessed by a quantitative reverse transcription PCR (qRT-PCR), targeting a conserved 68 nucleotide region of ORF3 gene, as previously described [66]. Viral RNA quantification was performed using the TaqMan Fast Virus 1-Step Master Mix (Invitrogen Ltd., Milan, Italy) in a $25-\mu \mathrm{L}$ volume comprising $5 \mu \mathrm{L}$ of extracted RNA and $20 \mu \mathrm{L}$ of master mix. Primers (JVHEVF: $5^{\prime}$-GGTGGTTTCTGGGGTGAC- $3^{\prime}$ and JHEVR: AGGGGTTGGTTGGATGAA-3') and TaqMan probe (JVHEVP: 5'-TGATTCTCAGCCCTTCGC-3') were used at concentrations of 200 and $100 \mathrm{nM}$, respectively. In order to standardize the system, the WHO international standard for HEV RNA (code 6329/10) was used. Tenfold serial dilutions (from $10^{0}$ to $10^{8}$ copies) of a plasmid containing the $68 \mathrm{bp}$ ORF3 fragment of a Gt3 HEV wild boar strain (HEV/WB/P6-15/ITA, accession no. KU508285) [58] were used in each PCR run.

All the samples were also tested by nested RT-PCR using the primer sets Fw1679/Rw1680 and intFw1681/intRw1682 [67] to amplify a 172-bp fragment of the methyltransferase region (ORF1) highly conserved within the species Orthohepevirus A.

Screening for other members of the genus Orthohepevirus was done by heminested RT-PCR (pan-hepevirus RT-PCR) using broadly reactive primers designed to amplify all members of the family Hepeviridae [68] and targeting a region of 338-bp of the viral RNA-dependent RNA polymerase (RdRp) complex.

\subsection{Statistical Analysis}

The data were analyzed using the Stata v.16.1 Software (StataCorp, 2016, www.stata.com). Calculation of the confidence intervals (CI) for the seroprevalence estimates was performed by Wilson score interval of $95 \%$. Univariate and multivariate logistic regression analyses were carried out to determine the association between detection of HEV antibodies in sheep and goats and different age groups. A $p$ value of $<0.05$ was considered statistically significant.

\subsection{Ethics Statement}

For this study, no ethical approval was required (Decreto Legislativo 4 March 2014, N. 26). Serum and fecal samples from wild ruminants were collected during the routinely monitoring activities performed by the National Reference Centre for Wild Animal Diseases (CeRMAS-IZS PLV), whilst samples from sheep and goats were collected only for veterinary diagnostic purposes.

\section{Results}

By screening 134 sheep serum samples, HEV antibodies were detected in a total of 29 sera with an overall prevalence of $21.6 \%$ (95\% CI $15.0-29.6 \%$ ) and $\mathrm{OD}_{450}$ values ranging from 0.17 to 1.96 (mean $\left.\mathrm{OD}_{450} 0.49\right)$. When assessing goat sera, the positivity rate was $11.4 \%(95 \%$ CI $7.0-17.2 \% ; 19 / 167)$ with $\mathrm{OD}_{450}$ comprised between 0.20 and 3.24 (mean $\mathrm{OD}_{450}$ 0.88). Analyzing the distribution of the seropositivity across the farms from the two regions investigated (Table 1), antibodies to HEV were found in $2 / 5$ sheep herds, located in the Piemonte region, with rates respectively of $18.7 \%$ (95\% CI 
10.6-29.3\%) and 36.6\% (95\% CI 22.1-53.1\%), whilst they were not detected in 3 sheep farms from Valle $\mathrm{d}$ 'Aosta. By converse, the prevalence rate in goats was $11.1 \%(10 / 90)$ in Piemonte and $11.7 \%(9 / 77)$ in Valle d'Aosta (Figure 2).

Table 1. Serological prevalence of Hepatitis E virus (HEV) in sheep and goat farms.

\begin{tabular}{|c|c|c|c|c|}
\hline Species & Region & Locality & Positive/Total (\%) & CI 95\% \\
\hline Sheep & Valle d'Aosta & Courmayeur & $0 / 6(0)$ & \\
\hline Sheep & Valle d'Aosta & Morgex & $0 / 6(0)$ & \\
\hline Sheep & Valle d'Aosta & Sarre & $0 / 6(0)$ & \\
\hline Sheep & Piemonte & Sampeyre & $15 / 41(36.6)$ & $22.1-53.1$ \\
\hline Sheep & Piemonte & Roccaforte Mondovì & $14 / 75$ (18.7) & $10.6-29.3$ \\
\hline Sheep-Total & & & $29 / 134(21.6)$ & $15.0-29.6$ \\
\hline Goats & Valle d'Aosta & Verrayes & $1 / 6(16.7)$ & $0.4-64.1$ \\
\hline Goats & Valle d'Aosta & Perloz & $3 / 6(50.0)$ & $11.8-88.2$ \\
\hline Goats & Valle d'Aosta & Perloz & $0 / 7(0)$ & \\
\hline Goats & Valle d'Aosta & Arnad & $1 / 4(25.0)$ & $0.6-80.6$ \\
\hline Goats & Valle d'Aosta & Pont St. Martin & $1 / 7(14.3)$ & $0.4-57.9$ \\
\hline Goats & Valle d'Aosta & Brusson & $2 / 5(40.0)$ & $5.3-85.3$ \\
\hline Goats & Valle d'Aosta & Chatillon & $1 / 6(16.7)$ & $0.4-57.9$ \\
\hline Goats & Valle d'Aosta & Gignod & $0 / 5(0)$ & \\
\hline Goats & Valle d'Aosta & Gignod & $0 / 5(0)$ & \\
\hline Goats & Valle d'Aosta & Cogne & $0 / 6(0)$ & \\
\hline Goats & Valle d'Aosta & Nus & $0 / 5(0)$ & \\
\hline Goats & Valle d'Aosta & Bionaz & $0 / 5(0)$ & \\
\hline Goats & Valle d'Aosta & Quart & $0 / 5(0)$ & \\
\hline Goats & Valle d'Aosta & Fenis & $0 / 5(0)$ & \\
\hline Goats & Piemonte & Brossasco & $10 / 40(25.0)$ & $13.0-41.2$ \\
\hline Goats & Piemonte & Narzole & $0 / 50(0)$ & \\
\hline Goats-Total & & & 19/167 (11.4) & 7.0-17.2 \\
\hline Total & & & 48/301 (15.9) & $11.8-20.0$ \\
\hline
\end{tabular}

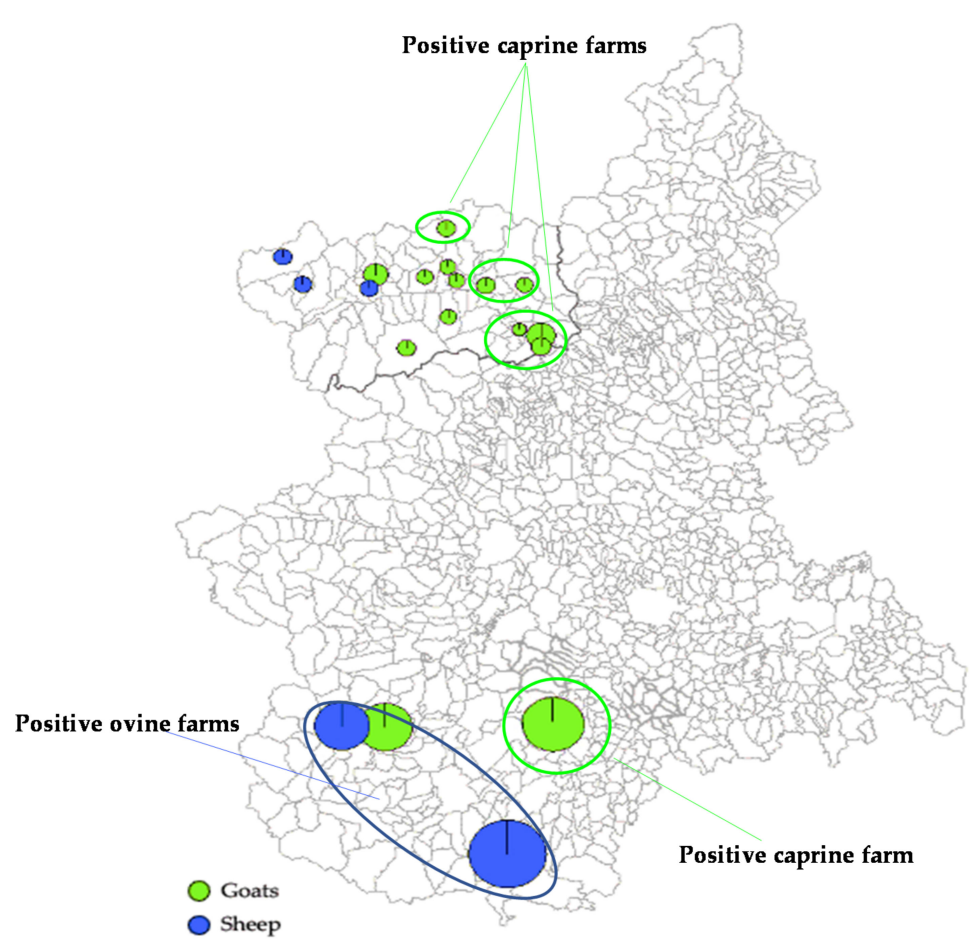

Figure 2. Geographical distribution (Piemonte and Valle d'Aosta) of sheep and goat farms positive for HEV antibodies. 
Information about age, available for a total of 286 animals, was used to estimate age-related difference in prevalence in both the species investigated (Figure 3). The highest rates were observed in the 3-4 years age group with rates of $13.6 \%$ for goats and $35.4 \%$ for sheep, whilst the lowest were detected in animals aged $<3$ years $(11.9 \%$ and $13.1 \%$, respectively). However, no statistically significant differences were found when compared the $3-4$ years age group to the $<3$ years or $>4$ years age groups.

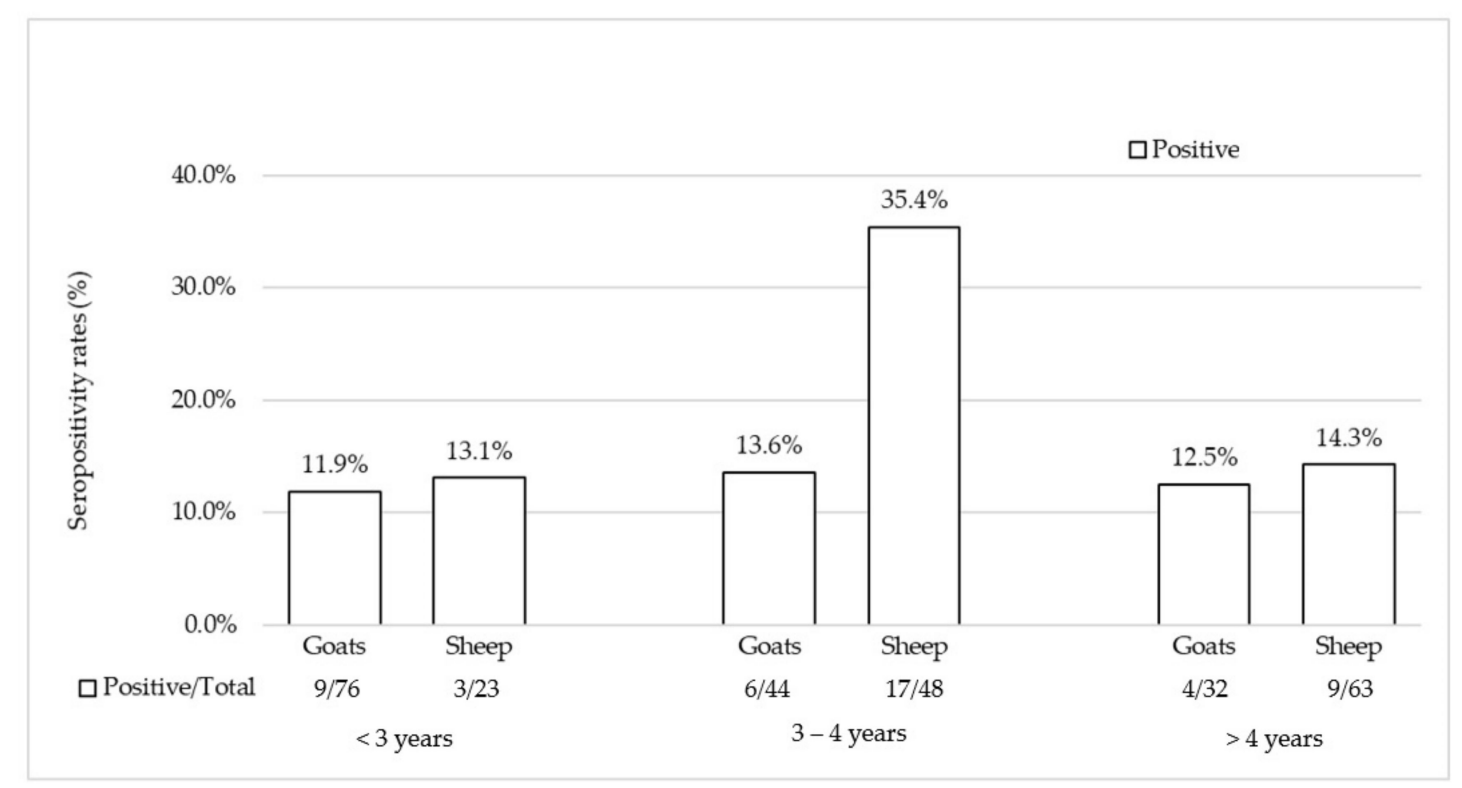

Figure 3. Antibodies to HEV in goat and sheep sera of different age groups.

Among the four species of wild ruminants, HEV antibodies were found in red deer, roe deer, and Alpine ibex with prevalence of $2.6 \%$ (1/38), 3.1\% (1/32), and 6.3\% (2/32), respectively, and with $\mathrm{OD}_{450}$ values ranging from 0.19 to 1.0 , while none of the sera collected from chamois reacted with HEV antigen (Table 2). All of the four positive sera were collected from animals sampled in the Valle d'Aosta region (Figure 4).

In order to explore the genetic heterogeneity of the HEVs circulating in the investigated geographical settings, all serum and fecal samples were screened molecularly. Out of the six ruminant species analyzed, HEV RNA was detected by qRT-PCR in four sheep fecal specimens (3.0\%; 4/134) collected from the two herds in which HEV antibody detection rates were $18.7 \%$ and $36.6 \%$, respectively. Viral loads ranging from $11 \times 10^{0}$ to $9.8 \times 10^{1} \mathrm{RNA}$ copies/gram faeces. By re-screening fecal and serum samples by qualitative RT-PCR, HEV RNA was not detected in any of the tested animals either by using a nested RT-PCR for the species Orthohepevirus A or using a pan-hepevirus RT-PCR.

Table 2. Serological prevalence of HEV in wild ruminants.

\begin{tabular}{cccc}
\hline Species & Region & Positive/Total (\%) & CI 95\% \\
\hline Red deer & Valle d'Aosta & $1 / 38(2.6)$ & $0.07-13.8$ \\
Roe deer & Valle d'Aosta & $1 / 32(3.1)$ & $0.08-16.2$ \\
Alpine ibex & Valle d'Aosta & $2 / 32(6.3)$ & $0.80-20.8$ \\
Chamois & Valle d'Aosta & $0 / 13(0)$ & \\
Total & & $\mathbf{4 / 1 1 5 ( 3 . 5 )}$ & $\mathbf{0 . 9 0 - 8 . 7}$ \\
\hline
\end{tabular}




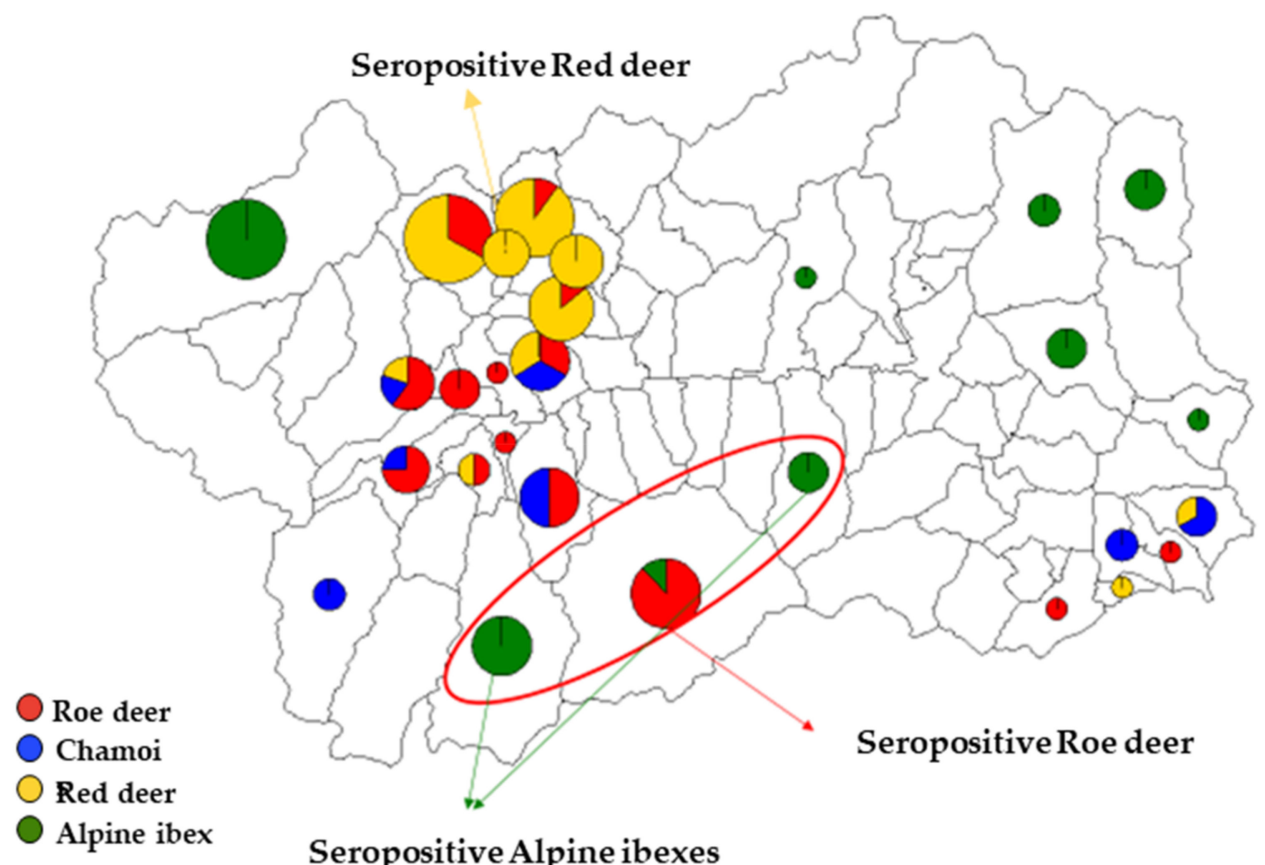

Figure 4. Maps of Valle d'Aosta Region showing the areas where seropositive wild ruminants were sampled.

\section{Discussion}

This surveillance study was initiated to draw a more complete picture of HEV epidemiology in ruminants by monitoring geographical areas in which the ecological interaction between wildlife and extensive farming livestock may allow ideal conditions for circulation of pathogens.

On serological screening, HEV-specific antibodies were detected in five of the six ruminant species assessed in this study, suggesting that these species are exposed to natural infection with HEV throughout their life, even if with marked differences in seroprevalence between domestic and wild animals.

With the exception of chamois, HEV antibodies were detected in all the wild species, including a population of Alpine ibex, whose susceptibility to HEV infection had never been documented thus far. These findings, while extending the HEV host spectrum to an additional distinct mammalian species, raises questions about the the exact nature of this serological positivity, as only antibodies have been detected. Indeed, in our analysis, HEV molecular evidence was not obtained in any of the wild ruminants included in the screening. Furthermore, we found an overall low seroprevalence rate for HEV (3.5\%; 4/115), confirming previous data collected during 2013-2015 surveillance from three distinct Italian Alpine regions [69], in which HEV antibodies were detected with rates of $1.2 \%$ $(2 / 172)$ in chamois and $0.8 \%(2 / 254)$ in red deer. Accordingly, it could be hypothesized a limited role of these wild animals in maintaining HEV circulation, at least in the investigated geographical settings. This restricted viral circulation could account for the low HEV detection rates observed in molecular $(3.7 \% ; 12 / 320)$ and serological $(4.9 \% ; 29 / 594)$ investigations reported previously [70] by testing liver and serum samples collected from wild boar populations in northwestern Italy (Piemonte, Liguria, and Valle d'Aosta). In addition to foodborne transmission, several studies [71-75] suggest that contact exposure with infected animals may represent a possible source of infection. The exposure risk to HEV infection in hunters was documented in a study performed in central Italy [72]. Viral RNA was found in $33.5 \%$ of wild boar liver samples tested and HEV antibodies have been detected in sera from hunters with a prevalence rate of $25 \%$ (5/20), with three positive samples containing also HEV RNA. The general low prevalence detected in wild ungulates may imply that the zoonotic transmission risks for hunters in the area assessed in this study are limited. 
A diverse scenario on HEV circulation was depicted in the population of small domestic ruminants investigated. Seroprevalence rates of $21.6 \%$ (29/134) were observed in sheep and of $11.4 \%(19 / 167)$ in goats. Furthermore, by qRT-PCR, HEV RNA was detected in four fecal samples collected from ovine farms. These findings seem to indicate that circulation of HEV among sheep and goat populations in Italy is more frequent than expected and it is not limited to a geographical area (southern Italy), considered at high-risk for human infection [76-78], where sustained viral circulation was demonstrated in pig herds or among wild boars $[58,79,80]$. In our analysis, many of the positive flocks were close to each other (Figure 2), remaining confined within an area of approximately $29.8 \mathrm{~km}^{2}$ in Piemonte and $14.9 \mathrm{~km}^{2}$ in Valle d'Aosta. Interestingly, the three sheep herds located a part in Valle d'Aosta, were found all seronegative for HEV. A similar geographical clustering was also observed for one roe deer and the two Alpine ibex possessing HEV antibodies (Figure 4), although no correlation in local distribution was revealed when comparing the seropositivities detected in wild ruminants with those from positive goat farms of the same region. These differences in HEV antibody detection rates could be related to a diverse distribution of HEV source within the territories investigated, underlining the needed of future studies enhancing the knowledges on HEV ecology in these specific areas. An age-related seroprevalence pattern was observed both in sheep and goats with the highest positivities in 3-4 years old animals and the lowest in the age groups $<3$ years. A similar age-related trend was observed in wild boars with the higher seroprevalence being reported in adults and subadults [12]. This trend may be consistent with a circulation of HEV among domestic ruminants at lower rates and more gradually. At the same time, the low seropositivity rates detected in older sheep and goats may be due to a fading immunity compatible with spillover HEV infection. Furthermore, the duration of protective immunity in domestic ruminants is still unknown and a short-term antibody response cannot be excluded. However, the low number of animals assessed in this study and the lack of homogeneity in the age stratification groups did not allow us to obtain any conclusive information. Additional studies based on a structured sampling could help to draw a more complete picture of HEV seroprevalence age-related pattern in sheep and goats.

In our molecular analysis, four sheep fecal specimens resulted positive for HEV RNA, although at low viral loads. Interestingly, all the molecularly positive sheep were seronegative, but sampled in both the farms in which HEV antibody detection rates were high (18.7\% and 36.6\%). This finding may be consistent with an active viral circulation within the two herds, at least at the time of sampling. In spite of several attempts to amplify viral RNA for sequencing by using broad-spectrum methods for species or family identification in various genome regions, none of the protocols were successful to generate sequence information.

Overall, the low prevalence rates and low viral loads observed in the virological investigation seem to suggest that sheep and goats are not a true reservoir of HEV, but more likely, they may be infected occasionally due to spillover events. It remains to establish exactly the HEV infection source for ruminants in the geographical setting investigated. Pigs and wild boars are known to be important reservoirs of HEV in industrialized countries. While data collected in northwestern Italy showed a low circulation of HEV in wild boars [70], local information on HEV epidemiology in pigs is still limited. With the exception of a survey performed in intensive pig farms from the Piemonte region in which viral RNA was found with a prevalence rate of 31.0\% [81], similar studies in Valle d'Aosta, an area characterized by a high concentration of small free-range pig farms, are still lacking. In this contest, the close contact between infected pigs and domestic ruminants may represent a potential pathway of viral transmission. Otherwise, we cannot rule out that environmental contaminations favoured using swine manure in agriculture may constitute a source of indirect HEV exposure to animals not living in close contact but sharing the same pasture areas. In a study investigating viral contamination sources in the swine industry, more than half of the samples positive for HEV RNA was collected around farm buildings and slaughterhouse [82]. In addition, studying HEV prevalence in swine slurry from farms located in northern Italy resulted in $80 \%$ of positive samples [83]. 
Meanwhile, whether domestic ruminants may represent spillover or true reservoir of HEV needed to be further investigated by detailed observational studies testing sera and stools, as well as different tissue samples including liver, muscle, and spleen. Finally, animal experiments would be required to investigate this hypothesis.

\section{Conclusions}

This survey provides data on the presence and diffusion of HEV in wild and domestic ruminants in two Alpine Italian regions, Piemonte and Valle d'Aosta, where livestock animals are in close contact with wildlife animals, thus complicating HEV ecology. The high seroprevalence observed in sheep and goats should be studied more in depth in order to establish their role in HEV transmission. Information on the risk factors associated with HEV infection in small domestic ruminants is still sparse $[52,55,57]$. In a recent serosurvey in Portugal [55], HEV antibodies have been found in $16.6 \%$ of the sheep sera and in $29.3 \%$ of workers occupationally exposed to sheep or to ovine edible products, but only in $16.1 \%$ of the control population. More recently, in a molecular and serological study conducted in upper Egypt [57], Gt3 HEV RNA was identified either in goat milk and liver samples. Accordingly, devising surveillance plans to ascertain the viral hazards for humans associated with the consumption of products of ovine and caprine origins is strongly suggested.

Author Contributions: Conceptualization, B.D.M., F.D.P., S.R.; methodology, B.D.M., F.D.P., A.P., P.F., V.S.; investigation, A.P., S.R., P.F., V.S., F.D.P., R.O.; writing-Original draft preparation, A.P., B.D.M., F.D.P., V.M., F.M.; analysis, M.C.B., G.R.; funding acquisition, B.D.M., S.R., R.O. All authors have read and agreed to the published version of the manuscript.

Funding: This research was funded by the Italian Ministry of Health (Progetto di Ricerca Corrente 2018 IZS PLV 12/18 RC Sorveglianza epidemiologica sulla circolazione in Italia Nord-Occidentale di virus enterici a carattere zoonosico emergenti e riemergenti nell'interfaccia domestico-selvatico).

Acknowledgments: We thank Irene Melegari for her assistance in the RNA extraction procedures of the samples. The authors also intend to thank Marco Ragionieri (AUSL Aosta), Giovanni Ercole (ASL CN2), Sergio Rinaudo (ASL CN1) for collection of biological samples, Regional wildlife offices and Aosta Valley Forestry Corp (CFVdA) for their technical assistance.

Conflicts of Interest: The authors declare no conflict of interest.

\section{References}

1. Kamar, N.; Izopet, J.; Pavio, N.; Aggarwal, R.; Labrique, A.; Wedemeyer, H.; Dalton, H.R. Hepatitis E virus infection. Nat. Rev. Dis. Primers 2017, 3, 17086. [CrossRef]

2. Takahashi, M.; Tanaka, T.; Takahashi, H.; Hoshino, Y.; Nagashima, S.; Jirintai; Mizuo, H.; Yazaki, Y.; Takagi, T.; Azuma, M.; et al. Hepatitis E Virus (HEV) strains in serum samples can replicate efficiently in cultured cells despite the coexistence of HEV antibodies: Characterization of HEV virions in blood circulation. J. Clin. Microbiol. 2010, 48, 1112-1125. [CrossRef] [PubMed]

3. Chapuy-Regaud, S.; Dubois, M.; Plisson-Chastang, C.; Bonnefois, T.; Lhomme, S.; Bertrand-Michel, J.; You, B.; Simoneau, S.; Gleizes, P.E.; Flan, B.; et al. Characterization of the lipid envelope of exosome encapsulated HEV particles protected from the immune response. Biochimie 2017, 141, 70-79. [CrossRef] [PubMed]

4. Smith, D.B.; Simmonds, P.; Jameel, S.; Emerson, S.U.; Harrison, T.J.; Meng, X.J.; Okamoto, H.; Van der Poel, W.H.; Purdy, M.A.; International Committee on the Taxonomy of Viruses Hepeviridae Study Group. Consensus proposals for classification of the family Hepeviridae. J. Gen. Virol. 2014, 95, $2223-2232$. [CrossRef] [PubMed]

5. Smith, D.B.; Izopet, J.; Nicot, F.; Simmonds, P.; Jameel, S.; Meng, X.J.; Norder, H.; Okamoto, H.; van der Poel, W.; Reuter, G.; et al. Update: Proposed reference sequences for subtypes of hepatitis E virus (species Orthohepevirus A). J. Gen. Virol. 2020, 101, 692-698. [CrossRef] [PubMed]

6. Kamar, N.; Bendall, R.; Legrand-Abravanel, F.; Xia, N.S.; Ijaz, S.; Izopet, J.; Dalton, H.R. Hepatitis E. Lancet 2012, 379, 2477-2488. [CrossRef]

7. Wang, B.; Meng, X.J. Hepatitis E virus: Host tropism and zoonotic infection. Curr. Opin. Microbiol. 2020, 59, 8-15. [CrossRef] 
8. Takahashi, M.; Nishizawa, T.; Sato, H.; Sato, Y.; Jirintai; Nagashima, S.; Okamoto, H. Analysis of the full-length genome of a hepatitis E virus isolate obtained from a wild boar in Japan that is classifiable into a novel genotype. J. Gen. Virol. 2011, 92, 902-908. [CrossRef]

9. Woo, P.C.; Lau, S.K.; Teng, J.L.; Tsang, A.K.; Joseph, M.; Wong, E.Y.; Tang, Y.; Sivakumar, S.; Xie, J.; Bai, R.; et al. New hepatitis E virus genotype in camels, the Middle East. Emerg. Infect. Dis. 2014, 20, 1044-1048. [CrossRef]

10. Woo, P.C.; Lau, S.K.; Teng, J.L.; Cao, K.Y.; Wernery, U.; Schountz, T.; Chiu, T.H.; Tsang, A.K.; Wong, P.C.; Wong, E.Y.; et al. New Hepatitis E Virus Genotype in Bactrian Camels, Xinjiang, China, 2013. Emerg. Infect. Dis. 2016, 22, 2219-2221. [CrossRef]

11. Lee, G.H.; Tan, B.H.; Teo, E.C.; Lim, S.G.; Dan, Y.Y.; Wee, A.; Aw, P.P.; Zhu, Y.; Hibberd, M.L.; Tan, C.K.; et al. Chronic Infection with Camelid Hepatitis E Virus in a Liver Transplant Recipient Who Regularly Consumes Camel Meat and Milk. Gastroenterology 2016, 150, 355-357. [CrossRef] [PubMed]

12. Pavio, N.; Doceul, V.; Bagdassarian, E.; Johne, R. Recent knowledge on hepatitis E virus in Suidae reservoirs and transmission routes to human. Vet. Res. 2017, 48, 78. [CrossRef] [PubMed]

13. Meng, X.J.; Purcell, R.H.; Halbur, P.G.; Lehman, J.R.; Webb, D.M.; Tsareva, T.S.; Haynes, J.S.; Thacker, B.J.; Emerson, S.U. A novel virus in swine is closely related to the human hepatitis $\mathrm{E}$ virus. Proc. Natl. Acad. Sci. USA 1997, 94, 9860-9865. [CrossRef] [PubMed]

14. Seminati, C.; Mateu, E.; Peralta, B.; de Deus, N.; Martin, M. Distribution of hepatitis E virus infection and its prevalence in pigs on commercial farms in Spain. Vet. J. 2008, 175, 130-132. [CrossRef]

15. Siochu, A.; Tzika, E.; Alexopoulos, C.; Kyriakis, S.C.; Froesner, G. First report of serological evidence of hepatitis E virus infection in swine in Northern Greece. Acta Vet. 2009, 59, 205-211. [CrossRef]

16. Lupulovic, D.; Lazic, S.; Prodanov-Radulovic, J.; Jiménez de Oya, N.; Escribano-Romero, E.; Saiz, J.C.; Petrovic, T. First Serological Study of Hepatitis E Virus Infection in Backyard Pigs from Serbia. Food Environ. Virol. 2010, 2, 110-113. [CrossRef]

17. Wacheck, S.; Werres, C.; Mohn, U.; Dorn, S.; Soutschek, E.; Fredriksson-Ahomaa, M.; Märtlbauer, E. Detection of IgM and IgG against hepatitis E virus in serum and meat juice samples from pigs at slaughter in Bavaria, Germany. Foodborne Pathog. Dis. 2012, 9, 655-660. [CrossRef]

18. Grierson, S.; Heaney, J.; Cheney, T.; Morgan, D.; Wyllie, S.; Powell, L.; Smith, D.; Ijaz, S.; Steinbach, F.; Choudhury, B.; et al. Prevalence of Hepatitis E Virus Infection in Pigs at the Time of Slaughter, United Kingdom, 2013. Emerg. Infect. Dis. 2015, 21, 1396-1401. [CrossRef]

19. Burri, C.; Vial, F.; Ryser-Degiorgis, M.P.; Schwermer, H.; Darling, K.; Reist, M.; Wu, N.; Beerli, O.; Schöning, J.; Cavassini, M.; et al. Seroprevalence of hepatitis E virus in domestic pigs and wild boars in Switzerland. Zoonoses Public Health 2014, 61, 537-544. [CrossRef]

20. O'Connor, M.; Roche, S.J.; Sammin, D. Seroprevalence of Hepatitis E virus infection in the Irish pig population. Ir. Vet. J. 2015, 68, 8. [CrossRef]

21. Lange, H.; Øverbø, J.; Borgen, K.; Dudman, S.; Hoddevik, G.; Urdahl, A.M.; Vold, L.; Sjurseth, S.K. Hepatitis E in Norway: Seroprevalence in humans and swine. Epidemiol. Infect. 2017, 145, 181-186. [CrossRef] [PubMed]

22. Tsachev, I.; Baymakova, M.; Ciccozzi, M.; Pepovich, R.; Kundurzhiev, T.; Marutsov, P.; Dimitrov, K.K.; Gospodinova, K.; Pishmisheva, M.; Pekova, L. Seroprevalence of Hepatitis E Virus Infection in Pigs from Southern Bulgaria. Vector Borne Zoonotic Dis. 2019, 19, 767-772. [CrossRef] [PubMed]

23. Tsachev, I.; Baymakova, M.; Pepovich, R.; Palova, N.; Marutsov, P.; Gospodinova, K.; Kundurzhiev, T.; Ciccozzi, M. High Seroprevalence of Hepatitis E Virus Infection Among East Balkan Swine (Sus scrofa) in Bulgaria: Preliminary Results. Pathogens 2020, 9, 911. [CrossRef] [PubMed]

24. Breum, S.Ø.; Hjulsager, C.K.; de Deus, N.; Segalés, J.; Larsen, L.E. Hepatitis E virus is highly prevalent in the Danish pig population. Vet. Microbiol. 2010, 146, 144-149. [CrossRef]

25. Savic, B.; Milicevic, V.; Bojkovski, J.; Kureljusic, B.; Ivetic, V.; Pavlovic, I. Detection rates of the swine torque teno viruses (TTVs), porcine circovirus type 2 (PCV2) and hepatitis E virus (HEV) in the livers of pigs with hepatitis. Vet. Res. Commun. 2010, 34, 641-648. [CrossRef] [PubMed]

26. Rose, N.; Lunazzi, A.; Dorenlor, V.; Merbah, T.; Eono, F.; Eloit, M.; Madec, F.; Pavio, N. High prevalence of Hepatitis E virus in French domestic pigs. Comp. Immunol. Microbiol. Infect. Dis. 2011, 34, 419-427. [CrossRef] [PubMed] 
27. Widén, F.; Sundqvist, L.; Matyi-Toth, A.; Metreveli, G.; Belák, S.; Hallgren, G.; Norder, H. Molecular epidemiology of hepatitis E virus in humans, pigs and wild boars in Sweden. Epidemiol. Infect. 2011, 139, 361-371. [CrossRef] [PubMed]

28. McCreary, C.; Martelli, F.; Grierson, S.; Ostanello, F.; Nevel, A.; Banks, M. Excretion of hepatitis E virus by pigs of different ages and its presence in slurry stores in the United Kingdom. Vet. Rec. 2008, 163, 261-265. [CrossRef]

29. Aniţă, A.; Gorgan, L.; Aniţă, D.; Oşlobanu, L.; Pavio, N.; Savuţa, G. Evidence of hepatitis E infection in swine and humans in the East Region of Romania. Int. J. Infect. Dis. 2014, 29, 232-237. [CrossRef]

30. Thiry, D.; Mauroy, A.; Saegerman, C.; Thomas, I.; Wautier, M.; Miry, C.; Czaplicki, G.; Berkvens, D.; Praet, N.; van der Poel, W.; et al. Estimation of hepatitis E virus (HEV) pig seroprevalence using ELISA and Western blot and comparison between human and pig HEV sequences in Belgium. Vet. Microbiol. 2014, 172, 407-414. [CrossRef]

31. Kantala, T.; Heinonen, M.; Oristo, S.; von Bonsdorff, C.H.; Maunula, L. Hepatitis E virus in young pigs in Finland and characterization of the isolated partial genomic sequences of genotype $3 \mathrm{HEV}$. Foodborne Pathog. Dis. 2015, 12, 253-260. [CrossRef] [PubMed]

32. Raspor Lainšček, P.; Toplak, I.; Kirbiš, A. A comprehensive study of hepatitis E virus infection in pigs entering a slaughterhouse in Slovenia. Vet. Microbiol. 2017, 212, 52-58. [CrossRef] [PubMed]

33. Porea, D.; Anita, A.; Demange, A.; Raileanu, C.; Oslobanu Ludu, L.; Anita, D.; Savuta, G.; Pavio, N. Molecular detection of hepatitis E virus in wild boar population in eastern Romania. Transbound. Emerg. Dis. 2018, 65, 527-533. [CrossRef] [PubMed]

34. De Deus, N.; Peralta, B.; Pina, S.; Allepuz, A.; Mateu, E.; Vidal, D.; Ruiz-Fons, F.; Martín, M.; Gortázar, C.; Segalés, J. Epidemiological study of hepatitis E virus infection in European wild boars (Sus scrofa) in Spain. Vet. Microbiol. 2008, 129, 163-170. [CrossRef] [PubMed]

35. Boadella, M.; Ruiz-Fons, J.F.; Vicente, J.; Martín, M.; Segalés, J.; Gortazar, C. Seroprevalence evolution of selected pathogens in Iberian wild boar. Transbound. Emerg. Dis. 2012, 59, 395-404. [CrossRef]

36. Žele, D.; Barry, A.F.; Hakze-van der Honing, R.W.; Vengušt, G.; van der Poel, W.H. Prevalence of Anti-Hepatitis E Virus Antibodies and First Detection of Hepatitis E Virus in Wild Boar in Slovenia. Vector Borne Zoonotic Dis. 2016, 16, 71-74. [CrossRef]

37. Jemeršić, L.; Keros, T.; Maltar, L.; Barbić, L.; Vilibić-Čavlek, T.; Jeličič, P.; Rode, O.D.; Prpić, J. Differences in hepatitis E virus (HEV) presence in naturally infected seropositive domestic pigs and wild boars-An indication of wild boars having an important role in HEV epidemiology. Vet. Arh. 2017, 87, 651-663. [CrossRef]

38. Takova, K.; Koynarski, T.; Minkov, I.; Ivanova, Z.; Toneva, V.; Zahmanova, G. Increasing Hepatitis E Virus Seroprevalence in Domestic Pigs and Wild Boar in Bulgaria. Animals 2020, 10, 1521. [CrossRef]

39. Tei, S.; Kitajima, N.; Takahashi, K.; Mishiro, S. Zoonotic transmission of hepatitis E virus from deer to human beings. Lancet 2003, 362, 371-373. [CrossRef]

40. Choi, J.Y.; Lee, J.M.; Jo, Y.W.; Min, H.J.; Kim, H.J.; Jung, W.T.; Lee, O.J.; Yun, H.; Yoon, Y.S. Genotype-4 hepatitis $\mathrm{E}$ in a human after ingesting roe deer meat in South Korea. Clin. Mol. Hepatol. 2013, 19, 309-314. [CrossRef]

41. Anheyer-Behmenburg, H.E.; Szabo, K.; Schotte, U.; Binder, A.; Klein, G.; Johne, R. Hepatitis E Virus in Wild Boars and Spillover Infection in Red and Roe Deer, Germany, 2013-2015. Emerg. Infect. Dis. 2017, 23, 130-133. [CrossRef] [PubMed]

42. Forgách, P.; Nowotny, N.; Erdélyi, K.; Boncz, A.; Zentai, J.; Szucs, G.; Reuter, G.; Bakonyi, T. Detection of hepatitis E virus in samples of animal origin collected in Hungary. Vet. Microbiol. 2010, 143, 106-116. [CrossRef] [PubMed]

43. Kubankova, M.; Kralik, P.; Lamka, J.; Zakovcik, V.; Dolanský, M.; Vasickova, P. Prevalence of Hepatitis E Virus in Populations of Wild Animals in Comparison with Animals Bred in Game Enclosures. Food. Environ. Virol. 2015, 7, 159-173. [CrossRef] [PubMed]

44. Lhomme, S.; Top, S.; Bertagnoli, S.; Dubois, M.; Guerin, J.L.; Izopet, J. Wildlife Reservoir for Hepatitis E Virus, Southwestern France. Emerg. Infect. Dis. 2015, 21, 1224-1226. [CrossRef] [PubMed]

45. Kukielka, D.; Rodriguez-Prieto, V.; Vicente, J.; Sánchez-Vizcaíno, J.M. Constant Hepatitis E Virus (HEV) Circulation in Wild Boar and Red Deer in Spain: An Increasing Concern Source of HEV Zoonotic Transmission. Transbound. Emerg. Dis. 2016, 63, e360-e368. [CrossRef] [PubMed] 
46. Neumann, S.; Hackl, S.S.; Piepenschneider, M.; Vina-Rodriguez, A.; Dremsek, P.; Ulrich, R.G.; Groschup, M.H.; Eiden, M. Serologic and Molecular Survey of Hepatitis E Virus in German Deer Populations. J. Wildl. Dis. 2016, 52, 106-113. [CrossRef]

47. Di Bartolo, I.; Ponterio, E.; Angeloni, G.; Morandi, F.; Ostanello, F.; Nicoloso, S.; Ruggeri, F.M. Presence of Hepatitis E Virus in a RED Deer (Cervus elaphus) Population in Central Italy. Transbound. Emerg. Dis. 2017, 64, 137-143. [CrossRef]

48. Thiry, D.; Mauroy, A.; Saegerman, C.; Licoppe, A.; Fett, T.; Thomas, I.; Brochier, B.; Thiry, E.; Linden, A. Belgian Wildlife as Potential Zoonotic Reservoir of Hepatitis E Virus. Transbound. Emerg. Dis. 2017, 64, 764-773. [CrossRef]

49. Spancerniene, U.; Grigas, J.; Buitkuviene, J.; Zymantiene, J.; Juozaitiene, V.; Stankeviciute, M.; Razukevicius, D.; Zienius, D.; Stankevicius, A. Prevalence and phylogenetic analysis of hepatitis E virus in pigs, wild boars, roe deer, red deer and moose in Lithuania. Acta Vet. Scand. 2018, 60, 13. [CrossRef]

50. Reuter, G.; Fodor, D.; Forgách, P.; Kátai, A.; Szucs, G. Characterization and zoonotic potential of endemic hepatitis E virus (HEV) strains in humans and animals in Hungary. J. Clin. Virol. 2009, 44, 277-281. [CrossRef]

51. Di Martino, B.; Di Profio, F.; Melegari, I.; Sarchese, V.; Robetto, S.; Marsilio, F.; Martella, V. Detection of hepatitis E virus (HEV) in goats. Virus Res. 2016, 225, 69-72. [CrossRef] [PubMed]

52. Long, F.; Yu, W.; Yang, C.; Wang, J.; Li, Y.; Li, Y.; Huang, F. High prevalence of hepatitis E virus infection in goats. J. Med. Virol. 2017, 89, 1981-1987. [CrossRef]

53. Li, S.; Liu, M.; Cong, J.; Zhou, Y.; Miao, Z. Detection and Characterization of Hepatitis E Virus in Goats at Slaughterhouse in Tai'an Region, China. Biomed Res. Int. 2017, 2017, 3723650. [CrossRef] [PubMed]

54. Sarchese, V.; Di Profio, F.; Melegari, I.; Palombieri, A.; Sanchez, S.B.; Arbuatti, A.; Ciuffetelli, M.; Marsilio, F.; Martella, V.; Di Martino, B. Hepatitis E virus in sheep in Italy. Transbound. Emerg. Dis. 2019, 66, 1120-1125. [CrossRef] [PubMed]

55. Mesquita, J.R.; Santos-Ferreira, N.; Ferreira, A.S.; Albuquerque, C.; Nóbrega, C.; Esteves, F.; Cruz, R.; Vala, H.; Nascimento, M. Increased risk of hepatitis E virus infection in workers occupationally exposed to sheep. Transbound. Emerg. Dis. 2020, 67, 1918-1921. [CrossRef] [PubMed]

56. Wu, J.; Si, F.; Jiang, C.; Li, T.; Jin, M. Molecular detection of hepatitis E virus in sheep from southern Xinjiang, China. Virus Genes 2015, 50, 410-417. [CrossRef] [PubMed]

57. El-Mokhtar, M.A.; Elkhawaga, A.A.; Sayed, I.M. Assessment of hepatitis E virus (HEV) in the edible goat products pointed out a risk for human infection in Upper Egypt. Int. J. Food Microbiol. 2020, 330, 108784. [CrossRef]

58. Di Profio, F.; Melegari, I.; Sarchese, V.; Robetto, S.; Marruchella, G.; Bona, M.C.; Orusa, R.; Martella, V.; Marsilio, F.; Di Martino, B. Detection and genetic characterization of hepatitis E virus (HEV) genotype 3 subtype $\mathrm{c}$ in wild boars in Italy. Arch. Virol. 2016, 161, 2829-2834. [CrossRef]

59. Lucarelli, C.; Spada, E.; Taliani, G.; Chionne, P.; Madonna, E.; Marcantonio, C.; Pezzotti, P.; Bruni, R.; La Rosa, G.; Pisani, G.; et al. High prevalence of anti-hepatitis E virus antibodies among blood donors in central Italy, February to March 2014. Euro Surveill. 2016, 21, 30299. [CrossRef]

60. Zhang, J.Z.; Im, S.W.; Lau, S.H.; Chau, T.N.; Lai, S.T.; Ng, S.P.; Peiris, M.; Tse, C.; Ng, T.K.; Ng, M.H. Occurrence of hepatitis E virus IgM, low avidity IgG serum antibodies, and viremia in sporadic cases of non-A, -B, and -C acute hepatitis. J. Med. Virol. 2002, 66, 40-48. [CrossRef]

61. Krumbholz, A.; Joel, S.; Neubert, A.; Dremsek, P.; Dürrwald, R.; Johne, R.; Hlinak, A.; Walther, M.; Lange, J.; Wutzler, P.; et al. Age-related and regional differences in the prevalence of hepatitis E virus-specific antibodies in pigs in Germany. Vet. Microbiol. 2013, 167, 394-402. [CrossRef] [PubMed]

62. Bassal, R.; Wax, M.; Shirazi, R.; Shohat, T.; Cohen, D.; David, D.; Abu-Mouch, S.; Abu-Ghanem, Y.; Mendelson, E.; Ben-Ari, Z.; et al. Seroprevalence of hepatitis E virus in dromedary camels, Bedouins, Muslim Arabs and Jews in Israel, 2009-2017. Epidemiol. Infect. 2019, 147, e92. [CrossRef] [PubMed]

63. Wang, L.; Teng, J.; Lau, S.; Sridhar, S.; Fu, H.; Gong, W.; Li, M.; Xu, Q.; He, Y.; Zhuang, H.; et al. Transmission of a Novel Genotype of Hepatitis E Virus from Bactrian Camels to Cynomolgus Macaques. J. Virol. 2019, 93, e02014-18. [CrossRef] [PubMed]

64. Eiden, M.; Dähnert, L.; Spoerel, S.; Vina-Rodriguez, A.; Schröder, R.; Conraths, F.J.; Groschup, M.H. Spatial-Temporal Dynamics of Hepatitis E Virus Infection in Foxes (Vulpes vulpes) in Federal State of Brandenburg, Germany, 1993-2012. Front. Microbiol. 2020, 11, 115. [CrossRef] [PubMed] 
65. Raj, V.S.; Smits, S.L.; Pas, S.D.; Provacia, L.B.; Moorman-Roest, H.; Osterhaus, A.D.; Haagmans, B.L. Novel hepatitis E virus in ferrets, The Netherlands. Emerg. Infect. Dis. 2012, 18, 1369-1370. [CrossRef] [PubMed]

66. Jothikumar, N.; Cromeans, T.L.; Robertson, B.H.; Meng, X.J.; Hill, V.R. A broadly reactive one-step real-time RT-PCR assay for rapid and sensitive detection of hepatitis E virus. J. Virol. Methods 2002, 131, 65-71. [CrossRef] [PubMed]

67. Fogeda, M.; Avellón, A.; Cilla, C.G.; Echevarría, J.M. Imported and autochthonous hepatitis E virus strains in Spain. J. Med. Virol. 2009, 81, 1743-1749. [CrossRef] [PubMed]

68. Drexler, J.F.; Seelen, A.; Corman, V.M.; Fumie Tateno, A.; Cottontail, V.; Melim Zerbinati, R.; Gloza-Rausch, F.; Klose, S.M.; Adu-Sarkodie, Y.; Oppong, S.K.; et al. Bats worldwide carry hepatitis E virus-related viruses that form a putative novel genus within the family Hepeviridae. J. Virol. 2012, 86, 9134-9147. [CrossRef]

69. Trogu, T.; Ferrari, N.; Formenti, N.; Filipello, V.; Pedrotti, L.; Viganò, R.; Lanfranchi, P.; Luzzago, C. Low Serologic Prevalences Suggest Sporadic Infections of Hepatitis E Virus in Chamois (Rupicapra rupicapra) and Red Deer (Cervus elaphus) in the Italian Alps. J. Wildl. Dis. 2020, 56, 443-446. [CrossRef]

70. Caruso, C.; Modesto, P.; Bertolini, S.; Peletto, S.; Acutis, P.L.; Dondo, A.; Robetto, S.; Mignone, W.; Orusa, R.; $\mathrm{Ru}, \mathrm{G}$;; et al. Serological and virological survey of hepatitis $\mathrm{E}$ virus in wild boar populations in northwestern Italy: Detection of HEV subtypes 3e and 3f. Arch. Virol. 2015, 160, 153-160. [CrossRef]

71. Chaussade, H.; Rigaud, E.; Allix, A.; Carpentier, A.; Touzé, A.; Delzescaux, D.; Choutet, P.; Garcia-Bonnet, N.; Coursaget, P. Hepatitis E virus seroprevalence and risk factors for individuals in working contact with animals. J. Clin. Virol. 2013, 58, 504-508. [CrossRef] [PubMed]

72. Montagnaro, S.; De Martinis, C.; Sasso, S.; Ciarcia, R.; Damiano, S.; Auletta, L.; Iovane, V.; Zottola, T.; Pagnini, U. Viral and Antibody Prevalence of Hepatitis E in European Wild Boars (Sus scrofa) and Hunters at Zoonotic Risk in the Latium Region. J. Comp. Pathol. 2015, 153, 1-8. [CrossRef] [PubMed]

73. Schielke, A.; Ibrahim, V.; Czogiel, I.; Faber, M.; Schrader, C.; Dremsek, P.; Ulrich, R.G.; Johne, R. Hepatitis E virus antibody prevalence in hunters from a district in Central Germany, 2013: A cross-sectional study providing evidence for the benefit of protective gloves during disembowelling of wild boars. BMC Infect. Dis. 2015, 15, 440. [CrossRef] [PubMed]

74. Dremsek, P.; Wenzel, J.J.; Johne, R.; Ziller, M.; Hofmann, J.; Groschup, M.H.; Werdermann, S.; Mohn, U.; Dorn, S.; Motz, M.; et al. Seroprevalence study in forestry workers from eastern Germany using novel genotype 3- and rat hepatitis E virus-specific immunoglobulin G ELISAs. Med. Microbiol. Immunol. 2012, 201, 189-200. [CrossRef] [PubMed]

75. Ivanova, A.; Tefanova, V.; Reshetnjak, I.; Kuznetsova, T.; Geller, J.; Lundkvist, Å.; Janson, M.; Neare, K.; Velström, K.; Jokelainen, P.; et al. Hepatitis E Virus in Domestic Pigs, Wild Boars, Pig Farm Workers, and Hunters in Estonia. Food Environ. Virol. 2015, 7, 403-412. [CrossRef]

76. Di Profio, F.; Melegari, I.; Palombieri, A.; Sarchese, V.; Arbuatti, A.; Fruci, P.; Marsilio, F.; Martella, V.; Di Martino, B. High prevalence of hepatitis E virus in raw sewage in Southern Italy. Virus Res. 2019, 272, 197710. [CrossRef]

77. Spada, E.; Pupella, S.; Pisani, G.; Bruni, R.; Chionne, P.; Madonna, E.; Villano, U.; Simeoni, M.; Fabi, S.; Marano, G.; et al. A nationwide retrospective study on prevalence of hepatitis E virus infection in Italian blood donors. Blood Transfus. 2018, 16, 413-421. [CrossRef]

78. Iaconelli, M.; Bonanno Ferraro, G.; Mancini, P.; Suffredini, E.; Veneri, C.; Ciccaglione, A.R.; Bruni, R.; Della Libera, S.; Bignami, F.; Brambilla, M.; et al. Nine-Year Nationwide Environmental Surveillance of Hepatitis E Virus in Urban Wastewaters in Italy (2011-2019). Int. J. Environ. Res. Public Health 2020, 17, 2059. [CrossRef]

79. Di Martino, B.; Di Profio, F.; Martella, V.; Di Felice, E.; Di Francesco, C.E.; Ceci, C.; Marsilio, F. Detection of hepatitis E virus in slaughtered pigs in Italy. Arch. Virol. 2010, 155, 103-106. [CrossRef]

80. Aprea, G.; Amoroso, M.G.; Di Bartolo, I.; D’Alessio, N.; Di Sabatino, D.; Boni, A.; Cioffi, B.; D’Angelantonio, D.; Scattolini, S.; De Sabato, L.; et al. Molecular detection and phylogenetic analysis of hepatitis E virus strains circulating in wild boars in south-central Italy. Transbound. Emerg. Dis. 2018, 65, e25-e31. [CrossRef]

81. Caruso, C.; Peletto, S.; Rosamilia, A.; Modesto, P.; Chiavacci, L.; Sona, B.; Balsamelli, F.; Ghisetti, V.; Acutis, P.L.; Pezzoni, G.; et al. Hepatitis E Virus: A Cross-Sectional Serological and Virological Study in Pigs and Humans at Zoonotic Risk within a High-Density Pig Farming Area. Transbound. Emerg. Dis. 2017, 64, 1443-1453. [CrossRef] [PubMed] 
82. Nantel-Fortier, N.; Letellier, A.; Lachapelle, V.; Fravalo, P.; L'Homme, Y.; Brassard, J. Detection and Phylogenetic Analysis of the Hepatitis E Virus in a Canadian Swine Production Network. Food Environ. Virol. 2016, 8, 296-304. [CrossRef] [PubMed]

83. La Rosa, G.; Della Libera, S.; Brambilla, M.; Bisaglia, C.; Pisani, G.; Ciccaglione, A.R.; Bruni, R.; Taffon, S.; Equestre, M.; Iaconelli, M. Hepatitis E Virus (Genotype 3) in Slurry Samples from Swine Farming Activities in Italy. Food. Environ. Virol. 2017, 9, 219-229. [CrossRef] [PubMed]

Publisher's Note: MDPI stays neutral with regard to jurisdictional claims in published maps and institutional affiliations.

(C) 2020 by the authors. Licensee MDPI, Basel, Switzerland. This article is an open access article distributed under the terms and conditions of the Creative Commons Attribution (CC BY) license (http://creativecommons.org/licenses/by/4.0/). 